\title{
EUFEMISME DAN DISFEMISME DALAM NOVEL "KORUPSI" KARYA PRAMOEDYA ANANTA TOER
}

\author{
Vioni Saputri, Syahrul Ramadhan, Yasnur Asri \\ Universitas Negeri Padang \\ Jalan Belibis, Air Tawar Barat, Padang, Sumatera Barat \\ Surel: vioni.saputri@@student.unp.ac.id
}

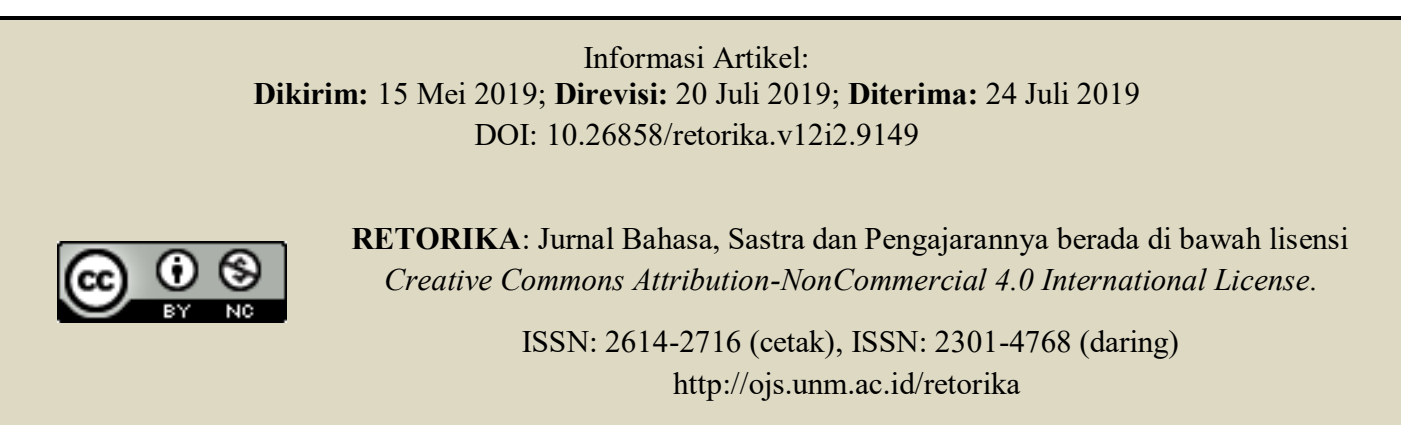

\begin{abstract}
Eufimism and Disphemism in "Corruption" Novel by Pramoedya Ananta Toer. The purpose of this study is to explain the form and function of the use of euphemism and disfemism in the novel "Corruption" by Pramoedya Ananta Toer. This type of research includes descriptive research. The data collection technique used is the note-reading technique. Data analysis used agih and equivalent methods. The validity of the data is obtained through intrarater and interrater. The results of this study are classifications of euphemism and disfemism. The classification is classified into words, phrases and sentences. In addition, the background to the use of euphemism and disfemism is the form in the novel "Corruption" in this study.
\end{abstract}

Keywords: euphemism, dysfemism, novel

\begin{abstract}
Abstrak: Eufemisme dan Disfemisme dalam Novel "Korupsi" Karya Pramoedya Ananta Toer. Tujuan dari penelitian ini adalah menjelaskan bentuk dan fungsi dari penggunaan eufemisme dan disfemisme dalam novel "Korupsi" karya Pramoedya Ananta Toer. Jenis penelitian termasuk penelitian deskriptif. Teknik pengumpulan data yang digunakan adalah teknik membaca catat. Analisis data yang digunakan metode agih dan padan. Keabsahan data diperoleh melalui intrarater dan interrater. Hasil penelitian ini adalah klasifikasi dari eufemisme dan disfemisme. Klasifikasi tersebut digolongkan menjadi kata, frasa dan kalimat. Selain itu, latar belakang penggunaan eufemisme dan disfemisme merupakan wujud yang ada dalam novel "Korupsi" ini dalam kajian ini.
\end{abstract}

Kata Kunci: eufemisme, disfemisme, novel 
Karya sastra merupakan ungkapan pribadi manusia berupa ide, gagasan, pengalaman, pemikiran, ataupun keyakinan dalam bentuk suatu gambaran kehidupan yang dapat dilukiskan dalam bentuk tulisan. Sebuah karya sastra tercipta berdasarkan imajinasi pengarang (Istiqomah, 2014:2). Kenyataan atau kebenaran dalam karya sastra tidak mungkin disamakan dengan kenyataan atau kebenaran di sekitar (Suharianto, dalam Istiqomah, 2014:2). Novel menjadi bagian dari karya sastra yang hingga kini masih digandrungi oleh penikmat dan pembaca.

Dalam novel, bahasa yang digunakan tentunya sebagai penyampai informasi kepada penikmat maupun pembacanya. Tentu bahasa yang disampaikan dapat diterima oleh pembaca. Namun demikian, dalam penggunaan bahasa sebuah novel dapat melambangkan hal-hal seperti penggunaan unsur eufemisme dan disfemisme.

Eufemisme dan disfemisme ini merupakan bagian dari gaya bahasa. Dalam sebuah karya sastra, tentunya ada disampaikan ungkapan tersebut. Bentuk yang disampaikan dari majas ini tidak terlepas dari sebuah bahasa. Majas tersebut dapat menghormati pembaca bahkan juga dapat menyindir. Namun demikian, konteksnya disesuaikan dengan kondisi dan tidak langsung tertuju secara langsung kepada pihak-pihak yang disindir.

Menurut Tarigan (2009:125-126), Hojati (2012: 553), Sutana (2012: 82), Laili (2016: 29), Sunarni (2017: 121), Norashikin, dkk (2017: 90), Almoayidi (2018: 3), dan Ojebuyi (2018:3) eufemisme adalah suatu penggunaan bahasa yang merupakan ungkapan-ungkapan halus untuk menggantikan ungkapan-ungkapan kasar atau kesat. Kurniawati (2011: 51), Khasan, dkk (2014: 2), Juwita (2018: 34), dan Pascarina (2018: 3) menjelaskan bahwa disfemisme adalah gaya bahasa yang digunakan untuk memperkasar agar terkesan negatif bagi mitra tutur. Jadi, dapat disimpulkan bahwa eufemisme adalah perubahan makna dalam bahasa (penghalusan makna), sedangkan disfemisme adalah pengasaran makna.

Ditinjau dari latar belakang penggunaannya, eufemisme dan disfemisme memiliki berbagai latar belakang (Allan dalam Kurniawati, 2011:52). Latar belakang penggunaan eufemisme (1) menghindari penggunaan kata-kata yang dapat menimbulkan kepanikan atau ketakutan, (2) tidak menyinggung, menghina, atau merendahkan seseorang, (3) mengurangi atau tidak menyinggung hal-hal yang menyakitkan atau tragedi, (4) berdiplomasi atau bertujuan retoris, (5) menggantikan kata-kata yang dilarang, tabu, vulgar atau bercitra negatif, (6) merahasiakan sesuatu, (7) menghormati atau menghargai orang lain, dan (8) menyindir atau mengkritik. Selanjutnya, disfemisme latar belakang penggunaannya ada sepuluh, yaitu (1) menyatakan hal yang tabu, tidak senonoh, asusila, (2) menunjukkan rasa tidak suka atau tidak setuju terhadap seseorang atau sesuatu, (3) penggambaran yang negatif tentang seseorang atau sesuatu, (4) mengungkapkan kemarahan atau kejengkelan, (5) mengumpat atau memaki, (6) menunjukkan rasa tidak hormat atau merendahkan seseorang, (7) mengolok-olok, mencela, atau menghina, (8) melebih-lebihkan sesuatu, (9) menghujat atau mengkritik, dan (10) menunjukkan sesuatu hal yang bernilai rendah.

Dalam novel "Korupsi" karya Pramoedya Ananta Toer, ditemukan unsur eufemisme dan disfemisme guna menyampaikan pesan kepada pembaca secara sopan dan mengungkapkan kritisi untuk seseorang mengenai realitas secara langsung. Pramoedya Ananta Toer merupakan pengarang dengan ciri khas tulisan yang menguraikan persoalan biografi, persoalan sejarah, dan kebanyakan bertendensi pada kemanusiaan, dan nilai-nilai humanis. Dari karya-karya tersebut banyak penghargaan yang diraih oleh sosok Pramoedya Ananta Toer, dimulai pada tahun 1988 hingga tahun 2000 beliau mengantongi sebanyak sebelas penghargaan.

Eufemisme dan disfemisme ini merupakan bagian dari majas. Perlu diungkapkannya dalam novel ini karena melibatkan kepada bentuk yang ditemukan, yaitu bentuk kata, frasa, serta kalimat yang sekiranya telah tertera dan sesuai dengan kajian topik tersebut. Penelitian ini penting dilakukan karena untuk menambah wawasan dalam membedakan ungkapan yang pantas atau tidaknya dan juga berpengaruh terhadap pengarang. Adanya eufemisme dan disfemisme ini membantu pengarang menyampaikan isi pemikirannya yang akan dituangkan dalam tulisannya sesuai dengan situasi yang sedang berlangsung tanpa maksud menyinggung secara menohok pada pihak-pihak tertentu. Lewat eufemisme dan disfemisme inilah penyampaian gagasan dapat digunakan sesuai konteksnya. Tujuan dan maksud penulis dapat tersampaikan denga tepat.

Penelitian tentang eufemisme maupun disfemisme telah banyak dilakukan, yakni pada pe- 
nelitian Khalidi dan Ernawita (2016) dengan judul "Unsur-unsur Eufemisme dalam Novel Jalan Retak Karya A. Samad Said" bahwa terdapat 35 unsur eufemisme yang dijumpai dalam novel retak. Selanjutnya, penelitian dari Meilasari, dkk. (2016) dengan judul "Analisis Terjemahan Ungkapan Eufemisme dan Disfemisme pada Teks Berita Online BBC" bahwa ditemukan ekspresi eufemisme dan disfemisme dalam 20 teks berita BBC dan terjemahannya.

Sebuah penelitian cenderung diperlukan kebaruan. Namun demikian, dalam penelitian ini, biasanya hanya berfokus pada surat kabar. Terdapat juga dapat novel, tetapi tidak banyak ditemukan dan juga hanya berfokus terhadap satu topik yang akan dikaji. Berbeda dengan penelitian ini, penulis memfokuskan pada dua topik, yakni eufemisme dan disfemisme. Objek yang dipilih penulis, yaitu novel "Korupsi" karya Pramoedya Ananta Toer karena novel tersebut belum dijadikan objek sebuah penelitian sastra. Pandangan penulis pun memilih novel "Korupsi" ini, dikarenakan penggunaan bahasa yang disampaikan pengarang lewat novel ini sesuai dengan topik yang peneliti kaji.

Novel "Korupsi" ini dipilih berdasarkan pertimbangan peneliti, yakni profil pengarang yang cenderung mengangkat cerita berdasarkan nilai-nilai humanisme. Dalam kehidupan bermasyarakat penggunaan ungkapan eufemisme dan disfemisme telah banyak dilakukan. Kajian ini menurut penulis cocok karena sesuai konteksnya. Alasan penulis juga memilih novel ini dikarenakan pembicaraan yang dikupas dalam novel ini tidak pernah hilang dari dahulu hingga sekarang. Berdasarkan alasan tersebut penulis bermaksud agar dapat menunjukkan Pramoedya ini penulis yang selalu menuangkan gagasannya lewat karya-karya bersifat humanis yang disesuaikan dengan situasi yang sedang berlangsung saat itu. Penelitian ini bertujuan untuk menganalisis dan mengetahui klasifikasi eufemisme dan disfemisme yang disampaikan dalam novel "Korupsi" ini.

\section{METODE}

Penelitian mengenai eufemisme dan disfemisme dalam novel "Korupsi" karya Pramoedya Ananta Toer termasuk penelitian deskriptif kualitatif. Data diperoleh dari novel "Korupsi". Sumber data penelitian ini berupa wacana novel
"Korupsi". Fokus penelitian ini adalah bentuk dan latar belakang dari penggunaan eufemisme dan disfemisme dalam novel "Korupsi" karya Pramoedya Ananta Toer.

Teknik pengumpulan data yang digunakan dalam penelitian ini adalah teknik baca dan teknik catat. Kedua teknik ini menjadi satu kesatuan yang saling bergantian dilakukan. Metode analisis data menggunakan metode padan dan agih. Metode padan merupakan cara yang digunakan untuk menganalisis data yang alat penentunya di luar dan terlepas dari bahasa yang bersangkutan. Metode padan yang digunakan adalah teknik padan referensial, yakni bersifat mental dari peneliti yang digunakan berupa kata kerja, benda, dan sebagainya. Metode agih adalah metode yang alat penentunya justru bagian dari bahasa itu sendiri. Metode agih yang digunakan adalah (1) teknik sisip, yakni dengan melesapkan unsur, (2) teknik lesap, yakni dengan menyisipkan unsur tertentu di unsur lingual yang ada, dan (3) teknik ganti, yakni menggartikan unsur lingual yang bersangkutan.

Keabsahan data diperoleh melalui dua hal yang dilakukan, yaitu intrarater dan interrater. Intrarater dilakukan bersama dengan peneliti untuk mencermati dan meneliti kembali data yang diperoleh dan meneliti kembali data-data yang telah dianalisis. Interrater dilakukan dengan mendiskusikan hasil penelitian bersama $e x-$ pert judgment, yaitu Prof. Dr. Syahrul, R., M.Pd.

\section{HASIL DAN PEMBAHASAN}

\section{Hasil}

Novel Korupsi karya Pramoedya Ananta Toer ini merupakan objek dari kajian eufemisme dan disfemisme. Dalam novel ini pengarang banyak menggunakan ungkapan tersebut bermaksud untuk memperhalus bahasa bahkan menyindir tokoh-tokoh yang ada pada masa itu. Penggunaan eufemisme dan disfemisme ini dikaji dalam dua kelompok, yakni bentuk dan latar belakang penggunaan dari eufemisme dan disfemisme.

\section{Eufemisme dalam Novel Korupsi Karya Pramoedya Ananta Toer}

Bentuk eufemisme yang ditemukan dalam novel Korupsi dikelompokkan menjadi tiga, yaitu (1) eufemisme berupa kata, (2) eufemisme berupa frasa, dan (3) eufemisme berupa kalimat. 
Tabel 1. Bentuk Eufemisme dalam Novel Korupsi Karya Pramoedya Ananta Toer

\begin{tabular}{lllll}
\hline $\begin{array}{l}\text { Kate } \\
\text {-gori }\end{array}$ & Jenis & $\begin{array}{l}\text { Rin- } \\
\text { cian }\end{array}$ & $\begin{array}{l}\text { Jum- } \\
\text { lah }\end{array}$ & Persen-tase \\
\hline Kata & $\begin{array}{l}\text { Kata } \\
\text { dasar }\end{array}$ & 12 & 25 & $15,24 \%$ \\
& & & \\
& $\begin{array}{l}\text { Kata } \\
\text { komp- } \\
\text { leks }\end{array}$ & 11 & & \\
& $\begin{array}{l}\text { Kata } \\
\text { ulang }\end{array}$ & 2 & \\
& & & \\
\end{tabular}

\begin{tabular}{lcc}
\hline Frasa & 64 & $39,02 \%$ \\
\hline $\begin{array}{l}\text { Kali- } \\
\text { mat }\end{array}$ & 75 & $45,73 \%$ \\
\hline Total & $\mathbf{1 6 4}$ & \\
\hline
\end{tabular}

Dari bentuk eufemisme yang telah diuraikan dalam tabel, ditemukan 164 bentuk eufemisme terdiri dari 25 bentuk kata dengan persentase $15,24 \%$, frasa 64 bentuk dengan presentase $39,02 \%$, dan kalimat 75 bentuk dengan persentase $45,73 \%$. Bentuk eufemisme pada segi kalimat ditemukan paling banyak dalam novel Korupsi karya Pramoedya Ananta Toer.

Eufemisme digunakan dengan maksud tidak menyinggung pihak-pihak tertentu. Pengarang menggunakan ungkapan eufemisme sesuai dengan konteks kalimatnya, selain ungkapan yang disampaikan lebih halus bahasa juga terlihat padu karena penyampaiannya lebih sesuai. Berikut ini bentuk eufemisme dan penjelasannya.

1) Tiap dinding dan tiap benda di kamar serasa merasa ikut menggigilkan kata yang itu-itu juga: korupsi! korupsi!

Ungkapan menggigilkan kata dikelompokkan eufemisme. Jika diartikan gigil bersinonim gemetar karena kedingingan, demam, ketakutan. Kata menggigilkan merupakan bentuk dari gabungan prefiks dan sufiks yang membentuk suatu kesatuan dinamakan konfiks. Kata menggigilkan dibentuk dari prefiks meng- ditambahkan dengan kata gigil sehingga menjadi menggigil. Sesudah itu barulah ditambah dengan sufiks kan menjadi menggigilkan.

Kata menggigil umumnya digunakan pada orang sakit, namun juga digunakan dalam konteks ketakutan. Pengarang telah menggunakan frasa yang tepat dalam kalimat. Jika kata yang digunakan sesuai sinonim maka makna yng disampaikan tidak padu dan kalimat yang dihasilkan terdengar rancu. Contohnya, Tiap dinding dan tiap benda di kamar serasa merasa ikut ketakutan kata yang itu-itu juga: korupsi! Korupsi! Dari contoh tersebut, kalimat yang disampaikan menjadi tidak nyambung walaupun menggunakan sinonim dari kata sebelumnya. Untuk itulah digunakan kata menggigilkan agar kalimat lebih sinkron dan bahasa yang disampaikan lebih menarik.

2) Suasana yang mencekik meliputi seluruh dapur di mana kami makan.

Penggunaan kalimat di atas dikategorikan ke dalam ungkapan eufemisme. Kata mencekik memiliki sinonim memegang dan mencekam leher, mematikan, serta menindas. Kata mencekik dibentuk dari prefiks me- yang bila dipasangkan dengan bentuk dasar berfonem awal d, $\mathrm{t}$, c, dan $\mathrm{j}$ akan mengalami morfofonemis menjadi men-. Kata me- bertemu kata dasar tindas dengan awalan $t$ yang menjadikan kalimat tersebut dibentuk, dari kata men- ditambah kata dasar cekik menjadi mencekik.

Penggunaan kata cekik biasanya disandingkan dengan kekerasan. Namun, kalimat di atas kerap kali ditemukan di dalam sebuah tulisan ataupun novel. Pengarang menggunakan kata mencekik bermaksud tidak langsung kepada maksudnya. Kata mencekik telah dianggap sesuai dalam kalimat tersebut. Jika digunakan sinonim maka makna yang disampaikan terlihat lebih menakutkan seperti contoh suasana yang mematikan, meliputi seluruh dapur tempat kami makan. Kata tersebut dapat digunakan, namun konteksnya terlihat lebih keras dan kasar. Digunakan kata mencekik agar makna tersampaikan tidak tampak namun langsung tertuju kepada pembaca. Penggunaan kata mencekik lebih sinkron dan padu dibandingkan sinonim bila digunakan.

Berdasarkan bentuk eufemisme tersebut, juga terdapat penggunaan eufemisme berdasarkan latar belakangnya. Akan diuraikan eufemisme tersebut sebagai berikut.

Pertama, eufemisme ditafsirkan untuk menghindari kata-kata yang dapat menimbulkan kepanikan atau ketakutan.

3) Dan kekecilan hatiku tak bisa diubah sekalipun telah empat lima kali ku-ulang-ulang manteraku. 
Kuulang-ulang manteraku merupakan bentuk eufemisme menghindari kepanikan. Hal tersebut kerap terjadi, contohnya ketika menghadapi sesuatu seperti berbicara di depan khalayak ramai tentunya sebelum itu akan berdoa dengan mulut komat-kamit untuk menghindari ketakutan ataupun kecemasan sebelum tampil. Sama halnya dengan kalimat diatas, maksud kuulangulang manteraku untuk menghindari ketakutan dengan melantunkan sesuatu dapat berupa doa ataupun komat-kamit semacamnya.

Kedua, eufemisme ditafsirkan memperhalus ucapan agar tidak menyinggung, menghina, atau merendahkan seseorang.

4) Order aku cabut kembali.

Cabut dapat diartikan sebagai tarik, ataupun ambil. Kata cabut tidak ada unsur untuk menyinggung, menghina, bahkan merendahkan. Namun, kata cabut sebagai ungkapan biasa yang digunakan pengarang. Jika menggunakan sinonim tarik atau ambil makna langsung tersampaikan dan unsur eufemisme tidak akan muncul.

Ketiga, eufemisme untuk mengurangi atau tidak menyinggung hal-hal yang menyakitkan atau tragedi.

5) Susu perlu bagi orang Indonesia, mereka kekurangan lemak.

Ungkapan mereka kekurangan lemak bermaksud menyampaikan yang sebenarnya. Karena daerah Indonesia bagian Timur banyak sekali anak-anak dengan gizi buruk. Walaupun sedikit menyinggung namun bukan hal yang menyakitkan dan ini sebagai bentuk informasi yang perlu diutarakan kepada pemerintah bahwa halhal seperti itu perlu sekali untuk diperhatikan.

Keempat, eufemisme untuk berdiplomasi atau bertujuan retoris.

6) Penjara itu tak kenal ampun, dingin dan garang sebagai gedungnya.

Kata penjara sudah diketahui sebagai tempat yang tidak bagus. Pembicaraan dalam novel ini berupa Korupsi yang nanti akan ada hubungannya dengan penjara. Terkait dengan kata penjara memiliki sinonim bui, sel, lembaga permasyarakatan. Penggunaan penjara merupa-kan bentuk eufemisme dan terdengar lebih halus daripada sinonimnya.
Kelima, eufemisme untuk menggantikan kata-kata yang dilarang, tabu, vulgar atau bercitra negatif.

7) Kalau korupsi suatu perbuatan jahat, bukankah kejahatan itu akan hilang lenyap karena jasaku padanya?

Kata korupsi bentuk penghalusan untuk menggantikan kata mencuri, penyelewengan atau penyalahgunaan uang negara. Jika menggunakan sinonim kalimat tersebut tidak akan padu dan tidak ada unsur eufemisme. Kata korupsi biasanya disandingkan dengan koruptor yakni pelaku. Koruptor biasanya disebut dengan tikus, karena kebiasaan tikus suka mencuri. Namun hal tersebut merupakan ungkapan kasar yang dimaksudkan disfemisme. Karena itulah kata korupsi menjadi kata yang telah dalam pengunaan kalimat tersebut.

Keenam, eufemisme ditafsirkan untuk merahasiakan sesuatu.

8) Nanti habis kantor kuangkat sebagian dari harta terpendam itu, langsir ke pasar Senen dan menjualnya di tempat toko kertas tangan kedua.

Harta terpendam itu yang dimaksudkan pengarang yaitu kertas-kertas yang dicuri untuk dijual. Pengarang menyampaikan dengan ungkapan harta terpendam itu, bermaksud merahasiakan bentuk harta tersebut. Ungkapan jika menggunakan maksud aslinya tidak akan terlihat bentuk eufemismenya.

Ketujuh, eufemisme ditafsirkan untuk menghormati orang lain.

9) Kuharapkan dengan huruf pangkal itu mereka mendapatkan kejayaan sebagaimana halku dahulu.

Ungkapan mereka mendapatkan kejayaan digunakan untuk memperhalus kata. Ungkapan tersebut digunakan untuk menghormati, karena ayahnya bernama Bakir dan memberikan nama keempat anaknya dengan awalan $B$ bermaksud menghargai agar anak-anaknya mendapatkan kejayaan sama seperti dirinya seketika dulu. Kalimat tersebut disampaikan pengarang menggunakan unsur eufemisme bermaksud menghaluskan kata.

Kedelapan, eufemisme ditafsirkan untuk menyindir atau mengkritik dengan halus. 
10) Ah, dahulu menjadi pegawai negeri adalah suatu kehormatan.

Ungkapan kehormatan bentuk kata yang halus dan ketika disandingkan seperti kalimat di atas bermaksud menyindir. Kalimat tersebut menyatakan bahwa dahulu saja menjadi pegawai negeri suatu kehormatan, karena kehidupan tokoh Bakir yang morat-marit dijelaskan bahwa kehidupan pegawai negeri itu susah. Hingga kini, pegawai negeri merupakan pekerjaan yang banyak peminatnya. Namun, oknum-oknum yang tidak puas akan gaji yang mereka terima selalu kurang, maka bualan seperti itu kerap kali terlontarkan hingga perilaku seperti korupsi banyak terjadi.

\section{Disfemisme dalam Novel Korupsi Karya Pramoedya Ananta Toer}

Bentuk eufemisme yang ditemukan dalam novel Korupsi dikelompokkan menjadi tiga, yaitu (1) disfemisme berupa kata, (2) disfemisme berupa frasa, dan (3) disfemisme berupa kalimat.

Bentuk disfemisme secara keseluruhan yang ditemukan dalam novel Korupsi karya Pramoedya Ananta Toer berjumlah 166 bentuk terdiri dari kata 42 bentuk dengan persentase $25,30 \%$, frasa 80 bentuk dengan presentase $48,19 \%$, dan kalimat 44 bentuk dengan persentase $26,50 \%$. Dari ketiga bentuk eufemisme segi frasa paling banyak dimuat pengarang dalam tulisannya.

Ungkapan disfemisme lebih banyak digunakan pengarang dibandingkan eufemisme. Pengarang menggunakan disfemisme berusaha untuk menyindir tokoh-tokoh yang ada dalam novel sesuai dengan realitas yang terjadi pada zaman itu berdasarkan profil pengarang yang menguraikan persoalan biografi, persoalan sejarah, dan kebanyakan bertendensi pada kemanusiaan, dan nilai-nilai humanis. Adapun bentuk dari disfemisme yang ditemukan dalam novel Korupsi karya Pramoedya Ananta Toer sebagai berikut.

1) Ia sungguh-sungguh pembantu yang tahu pekerjaannya.

Pembantu merupakan bentuk yang kasar atau disfemisme. Kata pembantu ini merupakan bentuk kata kompleks. Terjadi dari penambahan prefiks awalan $p e$ - bila dipasangkan dengan bentuk dasar berfonem $\mathrm{p}, \mathrm{b}$, dan $\mathrm{f}$ akan menga-lami morfofonemis menjadi pem-. Terbentuklah kata pembantu dari penggabungan prefiks pem- ditambah kata dasar bantu menjadi pembantu.

Tabel 2. Bentuk Disfemisme dalam Novel Korupsi Karya Pramoedya Ananta Toer

\begin{tabular}{lllll}
\hline $\begin{array}{l}\text { Kate- } \\
\text { gori }\end{array}$ & Jenis & $\begin{array}{l}\text { Rin- } \\
\text { cian }\end{array}$ & $\begin{array}{l}\text { Jum- } \\
\text { lah }\end{array}$ & $\begin{array}{l}\text { Persen- } \\
\text { tase }\end{array}$ \\
\hline Kata & $\begin{array}{l}\text { Kata } \\
\text { dasar }\end{array}$ & 35 & 42 & $25,30 \%$ \\
& & & \\
& & & \\
& $\begin{array}{l}\text { Kata } \\
\text { komp- } \\
\text { leks }\end{array}$ & 4 \\
& Kata & 3 & \\
\cline { 2 - 3 } & ulang & & \\
\hline Frasa & & & \\
\hline Kalimat & \multicolumn{3}{c}{40} & $48,19 \%$ \\
\hline Total & \multicolumn{3}{c}{$\mathbf{1 6 6}$} \\
\hline
\end{tabular}

Sinonim dari kata pembantu di dalam KBBI ialah orang upahan. Istilah pembantu sebelumnya disebut sebagai budak, namun terdengar kasar dan beralih menjadi pembantu. Sesudah itu kata pembantu dianggap menjadi kasar dan diganti menjadi asisten rumah tangga. Bentuk kata dari asisten rumah tangga terdengar lebih sopan dan halus namun tidak sesuai konteks dari kalimat diatas sampaikan.

Pengarang telah tepat menempatkan kata pembantu dalam kalimat tersebut. Jika digunakan sinonim akan sumbang kalimatnya menjadi Ia sungguh-sungguh orang upahan yang tahu pekerjaannya, jika digunakan kata budak sangatlah kasar penyampaiannya, dan jika kata $a$ sisten rumah tangga yang digunakan maka tidak akan sesuai dengan konteks kalimatnya. Kata pembantu sesuai disampaikan di zaman itu, karena novel ini diterbitkan pada tahun 1954, kata pembantu terdengar sopan dan sesuai. Berbeda di zaman sekarang yang telah mengganti menjadi asisten rumah tangga.

\section{2) Minta sama bini?}

Ungkapan tersebut dikelompokkan ke dalam disfemisme. Kata bini bersinonim perempuan yang menjadi pasangan sah dari seorang laki-laki atau istri. Ungkapan bini banyak disampaikan pengarang di dalam novel Korupsi ini daripada istri. Dalam novel, penggunaan kata istri cenderung kalimat yang akan disampaikan lebih halus. Novel Korupsi lebih banyak ditemukan disfemisme dibandingkan eufemisme, tidak he- 
ran jika penggunaan kata bini banyak ditemukan. Selain kata bini, istilah kawin juga banyak ditemukan dalam novel Korupsi.

Kata bini disampaikan memiliki makna kasar. Dipengaruhi tahun terbitnya novel, yaitu 1954, pada zaman itu penggunaan kata bini dianggap biasa. Namun di zaman sekarang cenderung kasar, dan kata bini mengalami pergeseran makna membaik menjadi istri. Tetapi dalam novel kata istri juga ada disinggung, namun ketika menggunakan kata istri kalimat yang disampaikan justru tidak menyinggung dan kasar sedikit pun. Kata bini di sini juga merupakan bentuk sindiran dalam novel karena konteksnya disfemisme, jika digunakan kata istri maka kalimat di atas berubah menjadi eufemisme, yaitu bentuk sopan atau halusnya dalam sebuah kalimat.

Dari bentuk eufemisme tersebut penggunaan disfemisme berdasarkan latar belakangnya terdapat 10 dalam novel Korupsi karya Pramoedya Anantar toer. Adapun latar belakang penggunaannya sebagai berikut.

Pertama,disfemisme ditafsirkan untuk menyatakan hal yang tabu, tidak senonoh, atau asusila.

3) Dan untuk menghabisi tetek-bengek itu segera kulontarkan:

Ungkapan tetek bengek di dalam KBBI berarti masalah yang kecil atau remeh. Namun jika diartikan per kata akan berbeda. Ungkapan tersebut merupakan bentuk disfemisme. Biasanya digunakan dalam konteks yang tidak bagus dan bersifat menyinggung. Kata tersebut sering dikaitkan dengan hal tabu dan tidak senonoh.

Kedua, disfemisme ditafsirkan untuk menunjukkan rasa tidak suka, tidak setuju terhadap seseorang atau sesuatu.

4) Kami butuh uang untuk mengusir warung di depan.

Kata mengusir dalam kalimat tersebut merupakan disfemisme menunjukkan rasa tidak suka. Bakir yang ingin memiliki rumahnya seutuhnya berniat untuk mengusir taoke yang menyewa tempatnya. Kata mengusir konteksnya lebih keras dan kasar, maka dari itu kata mengusir dikategorikan kedalam disfemisme.

Ketiga, disfemisme ditafsirkan untuk memberikan penggambaran negatif tentang seseorang.
5) Sirad selalu lemah lembut itu kini merupakan setan garang bagiku, ia merupakan bahaya, ia merupakan kucing kalau aku kelak jadi tikus.

Ungkapan pada kalimat tersebut mengibaratkan kepada tokoh hewan. Sirad sebagai kucing dan Bakir sebagai tikus. Dapat diartikan bahwa kucing sebagai pihak yang membantu seperti aparat, sedangkan tikus sebagai koruptor. Pengibaratan pada tokoh hewan merupakan bentuk kasar atau disfemisme yang disampaikan dalam novel ini.

Keempat, disfemisme ditafsirkan untuk mengungkapkan kemarahan atau kejengkelan.

6) Bukankah aku telah rampas kekuasaan itu dan mempergunakannya sendiri sejak kini?

Pada kalimat tersebut ungkapan rampas kekuasaan itu merupakan bentuk kejengkelan yang dialami Bakir. Kata rampas memiliki arti ambil dengan paksa. Bakir yang telah lama mengalami kemelaratan dalam hidupnya merasa marah dan jengkel hingga merampas kekuasaan yang telah dipergunakan yang digambarkan pengarang dalam novel. Kata rampas cenderung bersifat kasar dan dapat dikategorikan kedalam disfemisme.

Kelima, disfemisme ditafsirkan untuk mengumpat atau memaki.

\section{7) Persetan mereka!}

Kalimat yang disampaikan pengarang merupakan bentuk disfemisme. Disfemisme yang disampaikan disampaikan Bakir yang sedang mengumpat tentang kekuasaan serta opas rekannya di kantor. Disertai dengan tanda seru menggambarkan bahwa keadaan dari tokoh Bakir sangatlah kesal, hingga mengumpat seperti itu. Kata persetan bersinonim jahanam. Dari kalimat tersebut sudah dapat dikatgorikan ke dalam disfemisme.

Keenam, disfemisme ditafsirkan untuk menunjukkan rasa tidak hormat atau merendahkan seseorang.

8) Kita dapat menggaji babu, barangkali dua atau tiga.

Penggunaan kata babu dalam konteknya tidak hormat dan merendahkan seseorang. Babu diartikan sebagai pelayan, pembantu, budak, pe- 
nata laksana rumah tangga atau asisten rumah tangga. Kata babu mencolok seperti menghina, karena penulisan novel ini di tahun 1954, penggunaan kata itu masih banyak digunakan. Kata babu dapat dikelompokkan menjadi disfemisme, dan jika menggunakan sinonim yang tetap masuk kedalam kelompok disfemisme pada kata budak.

Ketujuh, disfemisme ditafsirkan untuk mengolok-olok, mencela, menghina.

9) Persetan di opas jahanam itu.

Bentuk ungkapan tersebut sangat kasar. Persetan diartikan sebagai jahanam. Jika digunakan sinonimnya akan muncul dua kata jahanam dan kalimat yang dihasilkan tidak sinkron. Penempatan kalimat telah sesuai, dan kata tersebut dapat dikelompokkan menjadi disfemisme yang memiliki unsur mengolok-olok.

Kedelapan, disfemisme ditafsirkan untuk melebih-lebihkan.

10) Tua-tua tak tahu diri, terdengar gerutu yang mengancam.

Tua-tua tak tahu diri, bentuk disfemisme yang melebih-lebihkan. Dikatakan melebihlebihkan, karena Bakir digambarkan memiliki sikap yang tidak sesuai dengan umurnya. Di sini pengarang melebih-lebihkan watak dan perilaku Bakir, selain melakukan korupsi juga menginginkan istri yang cantik dan muda.

Kesembilan, disfemisme ditafsirkan untuk menghujat atau mengkritik.

11) Ah, waktu ini aku kepingin semua makhluk di dunia ini bodoh-bodoh seperti kerbau yang bisa dituntun kian kemari semau hatiku.

Kalimat ditebalkan merupakan bentuk disfemisme yang menghujat semua semua manusia menjadi bodoh seperti kerbau yang dapat diperintah dan diatur sesuka hati. Penggunan kata bodoh dan pengibaratan hewan yakni kerbau merupakan bentuk disfemisme. Karena pengibaratan terhadap hewan termasuk bentuk yang kasar, terlebih pada kerbau yang sering digambarkan bahwa kerbau memiliki otak yang dungu dan mudah saja untuk diperintah-perintah.

Kesepuluh, disfemisme ditafsirkan untuk menunjukkan sesuatu hal yang bernilai rendah.
12) Kalau diri tak punya milik, diri menjadi budak.

Sama dengan kata babu yang telah dibahas, kata budak merupakan bentuk disfe-misme menunjukkan hal yang bernilai rendah. Budak dipandang rendah karena bekerja sebagai pesuruh atau membantu-bantu majikan menyelsaikan segala urusan. Namun konteks penyampaian dalam kalimat tersebut sangatlah kasar, dan dapat dikategorikan sebagai bentuk disfemisme.

\section{Pembahasan}

Berdasarkan analisis topik eufemisme dan disfemisme tersebut menghasilkan rincian yang mendetail pada bagian kata, frasa, dan kalimat maupun latar belakang penggunaan dalam novel "Korupsi" tersebut. Disampaikan bahwa topik disfemisme cenderung banyak ditemukan dibandingkan dengan eufemisme dengan perbedaan yang sedikit.

Eufemisme disampaikan pengarang dalam novel Korupsi. Eufemisme merupakan kata atau ungkapan ringan atau tidak langsung yang diganti dengan yang dianggap terlalu keras atau tumpul ketika merujuk pada sesuatu yang tidak menyenangkan atau memalukan (kamus Oxford dalam Killing, 2016:69). Penggunaan bahasa yang halus agar tidak menyinggung pihak manapun. Berbeda halnya dengan disfemisme merupakan usaha untuk mengganti kata yang maknanya halus atau bermakna biasa dengan kata yang maknanya kasar (Chaer dalam Khasan 2014: 2)

Dalam penelitian ini cenderung, jarang menganalisis novel Pramoedya menurut penulis. Topik ini berkesinambungan akan novel "Korupsi”. Eufemisme dan disfemisme banyak ditemukan dalam novel Korupsi. Ungkapan tersebut diungkapkan dalam setiap bab. Sesuai dengan ciri pengarang Pramoedya Ananta Toer yang lebih menguraikan persoalan biografi, sejarah, dan berhubungan pada kemanusiaan dan nilai humanis tentunya ditemukan ungkapan eufemisme dan disfemisme sebagai bentuk yang diungkapkan pengarang kepada pembaca dalam novelnya.

Keunikan eufemisme dan disfemisme ini akan gaya bahasa yang disampaikan beragam. Tingkat halus dan tidak sopannya pun berbedabeda, terlebih objek kajiannya novel "Korupsi". Banyak ditemukan dari dua topik tersebut, dan ternyata ungkapan yang Pramoedya tuangkan ternyata kerap digunakan dalam ragam bahasa 
sehari-hari. Walaupun kajian ini hanya berupa ungkapan sopan dan sebaliknya, dapat memberikan dampak besar khususnya bagi teoretik, penikmat dan pengajaran bahasa.

Implikasi yang didapatkan secara teoretik dapat memperluas pengetahuan mengenai ungkapan baik yang sesuai digunakan. Dilihat dari segi penikmat dan pembaca, dapat menambah wawasan akan informasi yang disampaikan pengarang. Dari novel "Korupsi" ini disampaikan kronologi kasus tersebut berlangsung dan bertahan hingga sekarang hingga meruak ke manamana. Selain penikmat dan pembaca mendapatkan hiburan, juga didapatkan informasi yang lebih meluas. Bagi pengajaran implikasi yang didapatkan adalah sebagai bahan kajian dalam membuat sebuah karya sastra dengan hal-hal dasar yang telah ada, tetapi dalam konteksnya tidak merugikan. Merugikan di sini maksudnya, eufemisme dan disfemisme ini merupakan ungkapan yang digunakan dalam hal menyampaikan maksud namun tidak langsung ke objeknya. Jadi, jika salah dalam mengungkapkan karya sastra bukan hanya tidak terbit karya tersebut, bahkan menjadi bumerang yang menjerumuskan. Seperti kasus yang sedang gencar saat ini mengenai "ikan asin". Maka dari itu, bagi pengajaran sebagai pengungkap gagasan dan pemikiran akan karya sastra yang akan dihasilkan.

Penelitian ini melengkapi pada kajian bentuk dan latar belakang penggunaan dari eufemisme dan disfemisme. Dalam penelitian sebelumnya, Khasan (2014) dengan objek penelitian berita utama surat kabar joglo semar memfokuskan pada pemakaian disfemisme. Hasilnya ada tiga, yakni (1) bentuk disfemisme yang ditemukan berupa bentuk kata dan frasa, (2) alasan penggunaan bentuk disfemisme, dan (3) dampak dari penggunaan disfemisme.

Penelitian kedua adalah Meilasari (2016) mengkaji analisis terjemahan ungkapan eufimisme dan disfemisme teks berita online BBC. Pada penelitian ini ditemukan kecenderungan penggunaan disfemisme. Segi penerjemahannya mempertahankan nilai rasa dan dominan ada penerjemahannya. Teknik penerjemahan yang dipilih dalam penelitian ini sebagian berdampak positif.

Penelitian terakhir adalah Khalidi (2017) objek penelitian novel Jalan Retak karya A. Samad Said. Penelitian ini berfokus pada unsur eufemisme dalam novel. Hasil yang ditemukan terdapat 35 unsur eufemisme dalam novel. Fak- tor utama penggunaan unsur eufemisme disebabkan keadaan dan status usia. Dalam penelitian ini tidak hanya kesantunan berbahasa yang diperhatikan, tetapi asas kesejahteraan hidup dalam sebuah masyarakat penuturnya.

Penelitian ini memiliki keterkaitan jika disejajarkan dengan tiga penelitian sebelumnya. Membahas mengenai eufemisme dan disfemisme bahkan terdapat juga objek yang sama, yakni novel. Dari penelitian ini dibuktikan dari bentuk klasifikasi seperti kata, frasa, kalimat, dan latar belakang dalam novel. Namun, peneliti memfokuskan kepada hal yang lebih banyak dijumpai dalam novel dalam penelitian ini dan juga novel yang dipilih merupakan novel yang telah sesuai dengan objek kajian yang peneliti kaji saaat ini. Untuk itu, kebaruan dari penelitian ini merangkup dari pembahasan yang ada dalam tiga penelitian sebelumnya, serta novel yang digunakan belum pernah diteliti.

\section{SIMPULAN}

Karya sastra merupakan bentuk penyampaian yang dapat dihasilkan dari imajinasi dan tertuang dalam lisan maupun tulisan. Novel sebagai suatu karya sastra sebagai bentuk penyampaian pikiran seseorang yang dituangkan dalam tulisan. Novel Korupsi karya Pramoedya Ananta Toer merupakan bentuk objek yang dipilih karena banyak mengandung ungkapan eufemisme dan disfemisme. Pramoedya yang cenderung mengangkat cerita berdasarkan persoalan biografi, persoalan sejarah, dan keba-nyakan bertendensi pada kemanusiaan, dan nilai-nilai humanis menjadi alasan kuat untuk dalam penentuan objek eufemisme dan disfemisme. Dalam novel Korupsi ini ditemukan sebanyak 164 bentuk eufemisme berdasarkan kategori bentuk kata, frasa, dan kalimat serta bentuk disfemisme ditemukan sebanyak 166 bentuk berdasarkan kategori bentuk kata, frasa, dan kalimat. Selain bentuk eufemisme dan disfemisme ditemukan juga penggunaan latar belakang eufismisme dan disfemisme.

\section{UCAPAN TERIMA KASIH}

Penulis menyampaikan ucapan terima kasih kepada reviewers yang telah memberikan komentar, kritik serta saran terhadap perbaikan naskah ini. Tanggapan yang diberikan membantu penulis meningkatkan kualitas artikel ini. 


\section{DAFTAR RUJUKAN}

Almoayidi, K.A. 2018. Euphemism as a Communicate Tool: A Descriptive Study of Hijazi and Southren Region Dialects Spoken in Saudi Arabia. Open Journal of Modern Linguistics, 8: 1-8. doi:10.4236/ojml.2018. 81001

Hojati, A. 2012. A Study of Euphemisms in the Context of English-speaking Media. International Journal of Linguistics, 4(4):552-562. doi:10. 5296/ijl.v4i4.2933

Juwita \& Agus. 2018. Penginovasian Bentuk Disfemisme pada Berita Online dan Relevansinya pada Bahan Ajar Bahasa Indonesia di SMP. Jurnal Pendikan Bahasa dan Sastra, 7(2): 3345.

Khasan, dkk. 2014. Pemakaian Disfemisme dalam Berita Utama Surat Kabar Joglo Semar. Basastra. 2(3): 1-12.

Kurniawati, H. 2011. Eufemisme dan Disfemisme dalam Spiegel Online. Litera. 10(1): 51-63.

Laili, E. N. 2016. Eufemisme dalam Wacana Lingkungan Sebagai Piranti Manifestasi Manipulasi Realitas: Perspektif Ekolinguistik Kritis. Jurnal Linguistik Terapan, 6(1): 26-36.
Meilasari, P. dkk. 2016. Analisis Terjemahan Ungkapan Eufemisme dan Disfemisme pada Teks Berita Online BBC. Journal of Linguistics. 1(2): 336-358.

Norashikin, dkk. 2017. Unsur Eufemisme dalam Novel Jalan Retak Karya A. Samad Said. Journal of Business and Social Development, 5(1): 88101.

Ojebuyi \& Abiodun. 2018. Nigerian Newspapers' Use of Euphemism in Selection and Presentation of News Photographs of Terror Acts. Sage Open. 1-14. doi: 10.1177/2158244018763954

Pascarina, H. 2018. Disfemisme dan Terjemahannya pada Teks Berita BBC Online, Leksema. 3(1): $1-10$.

Sunarni, N. \& Jonjon J. 2017. Eufemisme dalam Bahasa Jepang. Prosodi. 11(2): 119-126.

Sutana, D. 2012. Eufemisme Sebagai Tindak Komunikasi yang Berada dalam Bahasa Jawa. Madah, 3(1): 81-90. 